\begin{abstract}
ARTUR HAMRYSZCZAK* - LUBLIN
HUBERT MĄCIK** - RZESZÓW
\end{abstract}

\title{
PARAFIA I KOŚCIÓŁ W ZEMBORZYCACH W XVIII-XIX WIEKU
}

Zarówno zemborzycka parafia, jak i niezachowany, drewniany kościół pw. św. Marcina, który poprzedzał istniejący obecnie neogotycki kościół z lat 19061907, nie doczekały się dotąd szczegółowego opracowania. Początki parafii w Zemborzycach, która powstała zapewne niedługo po lokacji wsi, a wzmiankowana jest od początku XV wieku, oraz wygląd wcześniejszych zemborzyckich kościołów według opisów zawartych w wizytacjach biskupich z lat 1565-1603 omówił J. Chachaj ${ }^{1}$. Ogólny zarys historii parafii przedstawił zemborzycki regionalista R. Łoziński². Nie omówił on jednak szczegółowo zemborzyckiej świątyni z 1717 roku, której szczegółowe opisy zachowały się w lubelskich archiwach, a której rysunki pomiarowe, publikowane w niniejszym artykule, przechowywane są w Instytucie Sztuki Polskiej Akademii Nauk w Warszawie.

W 1748 roku parafia zemborzycka, według zachowanej wizytacji biskupiej $\mathrm{z}$ tego roku ${ }^{3}$, obejmowała sześć miejscowości: Zemborzyce, Krężnica (filia), Trzeszkowice ${ }^{4}$, Osmolice, Prawiedniki i Żabia Wola. Na podstawie informacji z parafialnych ksiąg metrykalnych (Libri baptisatorum, copulatorum et mortuorum) prowadzonych od 8 stycznia 1747 roku do 29 lutego 1748 roku, możemy ustalić podstawowe dane dotyczące ludności. We wspomnianym czasie w parafii zembo-

\footnotetext{
* Artur Hamryszczak - dr historii, asystent naukowy w Ośrodku Archiwów Bibliotek i Muzeów Kościelnych KUL, e-mail: artur.hamryszczak@kul.pl

** Hubert Mącik - dr historii sztuki, adiunkt w Instytucie Archeologii, Uniwersytet Rzeszowski, e-mail: hubertmacik@gmail.com

${ }^{1}$ J. Chachaj, Bliżej schizmatyków niż Krakowa... Archidiakonat lubelski w XV i XVI wieku, Lublin 2012, s. 299; tenże, Zemborzyce w XIV-XVIII w., w: Zemborzyce, red. H. Mącik, J. Chachaj, D. Szulc, Lublin 2016 (w serii: Lublin. 700-lecie. Historia dzielnic, red serii D. Szulc, H. Mącik, s. 18.

${ }^{2}$ R. Łoziński, Zemborzyce. Studia z dziejów wsi i dzielnicy miasta, Lublin 2005, s. 79-87.

${ }^{3}$ Archiwum Archidiecezjalne Lubelskie (dalej: AAL), sygn. A, nr 103, Status ecclesiarum parochialium decanatus Parczoviensis et Chodeliensis ex anno 1748, s. 140-147.

${ }^{4}$ Obecne Strzeszkowice.
} 
rzyckiej udzielono chrztu 25 dzieciom (14 chłopcom, 11 dziewczynkom), zmarło 8 osób, a małżeństwo zawarło 15 par. Wszystkich zobowiązanych do spowiedzi paschalnej (oprócz dzieci) w parafii zemborzyckiej było do 1270 osób ${ }^{5}$. Niestety w innym miejscu, wizytacja podaje liczbę do 2000 osób ${ }^{6}$, więc nie bardzo wiadomo, którą liczbę należy uznać za właściwą.

Należy również wspomnieć, że na terenie parafii mieszkało ok. 60 Żydów. Byli oni arendarzami oraz zajmowali się handlem. Również w Krężnicy, w posiadłości ziemskiej dziedziców Suchodolskich, którzy byli kalwinami, żyło pięciu Żydów?

W parafii funkcjonował szpital, który mieścił się w starym budynku, składającym się z dwóch izb. W jednej mieszkały cztery staruszki, a w drugiej trzech mężczyzn ${ }^{8}$.

Do uposażenia parafii należały w Zemborzycach następujące grunty: dwa łany i półłanek pola, które rozciągało się do granicy Konopnicy oraz łan łąki za rzeką Bystrzyca. Ponadto pleban posiadał ogród o wielkości łana oraz prawo połowu ryb na rzece Bystrzyca 9 . Do parafii należał również browar oraz nowa karczma, $\mathrm{z}$ prawem propinacji. Jej funkcjonowanie było jednak bardzo kłopotliwe, ponieważ sprzedawany mieszkańcom alkohol przeszkadzał w godnym przeżywaniu przez nich świąt ${ }^{10}$.

Na łące plebańskiej nazywanej Królewszczyzna pracowali czterej poddani: Feliks Gargas, pracujący pięć dni w tygodniu oraz Szymon Kotek, Szymon Jakobusek i Albertus Sołtysek. Było również pięciu poddanych zagrodników (hortulani) którzy pracowali ze sprzężajem trzy dni w tygodniu. Ponadto dwaj pracowali jeden dzień w tygodniu ze sprzężajem: Krzysztof (Christoforus) Kabecki i Jakub (Jakobus) Więcek. Obydwaj mieli wydzieloną dla siebie część ogrodu plebańskiego ${ }^{11}$.

Plebanem zemborzyckim był w 1748 roku kanonik zamojski, Józef Głęgier. Został on ochrzczony 1 stycznia 1709 roku, a święcenia kapłańskie przyjął z rąk bpa kijowskiego Samuela Jana Ożgi. W dniu 7 sierpnia 1736 roku został prepozytem sokalskim, a od 10 marca 1738 roku - kanonikiem zamojskim, dzięki rekomendacji Tomasza Antoniego Zamojskiego, ordynata zamojskiego i patrona kolegiaty zamojskiej. W dniu 2 października 1741 roku nominowany został na proboszcza Zemborzyc i kościoła filialnego w Krężnicy. Ks. J. Głęgier ukończył kolegium jezuickie oraz odbył studia filozoficzno-teologiczne w Akademii Zamojskiej. Dwa lata studiował również w bliżej nieokreślonym seminarium duchownym ${ }^{12}$.

\footnotetext{
${ }^{5}$ AAL, sygn. A, nr 103, Status ecclesiarum parochialium, k. 197v-198.

${ }^{6}$ Tamże, k. 199.

${ }^{7}$ Tamże, k. 198.

${ }^{8}$ Tamże, k. 199v.

${ }^{9}$ Tamże, k. $198 \mathrm{v}$.

${ }^{10}$ Tamże, k. 199.

${ }^{11}$ Tamże.

${ }^{12}$ Tamże, k. 199-199v.
} 
W parafii pracował również organista, który swoją służbę objął w 1732 roku. Za swoją pracę otrzymywał rocznie 60 florenów oraz 8 korców bliżej nieokreślonych zbóż $\dot{1}^{13}$.

Następna zachowana wizytacja parafii zemborzyckiej pochodzi z $1781 \mathrm{roku}^{14}$, czyli od poprzedniej minęło 33 lata.

Plebanem był wówczas ks. Sebastian Krakowiecki, mansjonarz kościoła Św. Trójcy na Zamku lubelskim i kanonik kolegiaty. Urodził się w 1732 roku, a święcenia przyjął w 1761 roku. Parafię zemborzycką i krężnicką objął w 1775 roku $^{15}$. Pomocą w duszpasterstwie służył mu, za zgodą oficjum i prowincjała, ks. Ignacy, karmelita trzewiczkowy z Lublina, który mieszkał na plebani ${ }^{16}$.

Podczas wspomnianej wizytacji bardzo szczegółowo opisane zostało gospodarstwo plebańskie ${ }^{17}$. Zabudowania plebańskie były zlokalizowane na zachód od starego kościoła, na terenie dzisiejszego kościoła i parkingu. Budynki te były $\mathrm{z}$ drewna i co kilkadziesiąt lat wymieniano je na nowe. W 1779 roku, staraniem rządcy parafii ks. Krakowieckiego, wybudowana została nowa plebania, która znajdowała się niedaleko kościoła. Był to obszerny budynek o formie niewielkiego dworu, o rozmiarach $40 \times 20$ łokci (ok. $24 \times 12 \mathrm{~m}$ ), postawiony na podmurówce, jak wynika z opisu, o dwutraktowym układzie wnętrza, składający się z kilku pomieszczeń. Od strony południowej znajdowały się dwa pokoje „zimne”, które wspólnie ogrzewał jeden piec oraz dwa pokoje „letnie” z garderobą. Wszystkie te pomieszczenia posiadały okna z okiennicami oraz drzwi z zamkami francuskimi. Być może opisywane pokoje miały charakter przechodni, skoro zanotowano, że było w nich siedem zamków drzwiowych. W środku plebanii znajdowała się sień z drzwiami ,dubeltowemi ${ }^{18 ”, ~ z a o p a t r z o n y m i ~ w ~ w i e l k i ~ z a m e k ~ f r a n c u s k i . ~ P r z e d ~ s i e-~}$ nią znajdował się ganek z trzema oknami z okiennicami, natomiast za nią - kuchnia. W sieni stał duży murowany komin, którego podstawa sięgała fundamentów budynków.

Z tyłu kuchni, znajdował się pokój, którego ściany obłożone były tarcicami. Pełnił on najprawdopodobniej rolę salonu, ponieważ był w nim biały piec i kominek. Wejście do niego znajdowało się w garderobie, natomiast wyjście z pokoju skierowane było do kuchni. Drzwi były zaopatrzone w zamki francuskie. Pod wspomnianym pokojem znajdowała się murowana piwnica.

Po drugiej stronie sieni, najprawdopodobniej od strony północnej, znajdowała się duża izba i alkierz, w którym stał piec o dwóch kominach. Prawdopodobnie również te pomieszczenia posiadały wspólne drzwi. Obok nich znajdowała się spiżarnia, a także sień czeladnia. Wizytator policzył dokładnie, że w całym budynku (oprócz ganku) jest 12 okien z okiennicami oraz 15 drzwi.

13 Tamże, k. 199v.

${ }^{14}$ AAL, sygn. A 105, Akta wizyty generalnej dekanatów: chodelskiego, urzędowskiego i kazimierskiego w diecezji krakowskiej z lat 1781-1782, s. 140-147.

15 Tamże, s. 147; J. Szczepaniak, Spis prepozytów i plebanów diecezji krakowskiej (XVIII w.), Kraków 2008, s. 179.

${ }^{16}$ AAL, sygn. A 105, Akta wizyty generalnej dekanatów, s. 147.

17 Tamże, s. 145.

${ }^{18}$ Drzwi zewnętrze i wewnętrzne w jednej futrynie. 
Naprzeciwko plebanii, po drugiej stronie podwórza znajdował się budynek starego folwarku, który był w części wyremontowany. Składał się on z małego pomieszczenia z alkierzem. Pośrodku była kuchnia, a po przeciwnej stronie zrujnowana piekarnia. W skład zabudowań gospodarczych wchodziły nadto: spichlerz, stajnia, obora, wołownia, stajenki, oraz chlewy, które zbudował teraźniejszy pleban. Były również „pułtory stodoły stare, stodoła duża y drugiey połowa”"19.

Na placu kościelnym stał również budynek dla organisty, który wybudowano w 1777 roku. Składał się on z pokoju, alkierza, sieni i komórki. Mieszkał w nim organista Hieronim Kubecki, który miał 27 lat i pracował w parafii od 1777 roku $^{20}$.

Szpital parafialny mieścił się w starym budynku, który wymagał remontu. Jednak z powodu braku zapisanych funduszy na jego funkcjonowanie, nie wykonywano żadnych napraw. Nowy szpital wzniesiono w 1784 roku staraniem ks. Krakowieckiego. Było również osiem domków (chałupki) w których mieszkali poddani plebana. Jednak trzy z nich były bardzo stare, a czwarty w ruinie. Także karczma plebańska była bardzo stara i potrzebowała remontu. Nie było już budynku browaru, który według informacji, spalił się kilkanaście lat wcześniej ${ }^{21}$.

Jak można zauważyć gospodarstwo plebańskie było bardzo obszerne. Pracowało w nim 11 osób. Dodatkowo ośmiu poddanych chłopów z Zemborzyc pracowało na polu plebańskim: trzech z nich - jeden dzień w tygodniu, zaś pięciu - trzy dni w tygodniu ${ }^{22}$.

W 1849 roku, po śmierci proboszcza - ks. Borejki, opisano drobiazgowo istniejące wtedy budynki przy kościele w Zemborzycach ${ }^{23}$. Oprócz opisanego wyżej szczegółowo domu plebana z 1779 roku, w skład zabudowań przy kościele wchodziły wówczas:

- dom czeladni, położony naprzeciw plebanii, przy drodze do kościoła, zbudowany z tartego drzewa, pokryty słomą o rozmiarach $32 \times 12$ łokci (ok. 18,5×7 m), $\mathrm{z}$ trzema izbami wewnątrz, ogrzewanymi piecami;

- wikaria „z drzewa rzniętego" o rozmiarach $21 \times 10$ łokci (ok. 12×6 m), która była wówczas zamieszkana przez organistę;

- szpital o czterech izbach z piecami chlebowymi i ogrzewanych kominkami, wystawiony w 1840 roku po pożarze poprzedniego w roku 1839 , miał rozmiary $20 \times 16$ łokci (ok. $12 \times 9 \mathrm{~m}$ );

- karczma plebańska, wystawiona w 1787 roku, była wówczas w bardzo złym stanie, izba, sień i komora były bez podług, pokryta była słomą, a komin miała drewniany, oblepiony gliną;

\footnotetext{
${ }^{19}$ AAL, sygn. A 105, Akta wizyty generalnej dekanatów, s. 145.

${ }^{20}$ Tamże, s. 147.

${ }^{21}$ Tamże, s. 145.

${ }^{22}$ Tamże.

${ }^{23}$ Archiwum Państwowe w Lublinie (APL), Komisja Województwa Lubelskiego i Rząd Gubernialny Lubelski, Wydział Administracyjny, sygn. 1684: Akta szczegółowe tyczące się Kościoła Zemborzyckiego funduszów i avuslów, vol. 1, Inwentarz Fundi Instructi Kościoła parafialnego Zemborzyckiego łącznie z filialnym Krężnickim... (dalej: Inwentarz 1849), brak paginacji.
} 
- budynki gospodarcze: stajnia, wozownia, spichlerz, obora i obszerne stodoły, zlokalizowane na zachód od kościoła, w miejscu, w którym dzisiaj stoi kościół neogotycki z lat 1906-190724.

Można zakładać, że większość z nich kontynuowała lokalizację budynków omówionych w wizytacji z roku 1781. Wszystkie te budynki były drewniane, żaden z nich nie zachował się.

Najstarszym elementem kościoła była murowana zakrystia, wzniesiona przy poprzednim, zapewne drugim z kolei, drewnianym kościele w 2. ćwierci XVII wieku ${ }^{25}$. Murowane zakrystie przy drewnianych kościołach były stosunkowo częstym zjawiskiem w XVII wieku na terenie Rzeczypospolitej - przechowywano w nich oprócz paramentów kościelnych, także dokumenty i księgi parafialne. Zemborzycka zakrystia miała rzut zbliżony do kwadratu, była przekryta sklepieniem kolebkowym z lunetami, wspartym na ozdobnym profilowanym gzymsie, a jej wnętrze oświetlało jedno niewielkie okno od strony wschodniej. Prowadziły do niej drzwi z zewnątrz, od strony zachodniej oraz od wnętrza prezbiterium kościoła - od południa. Jej wygląd, podobnie jak wygląd drewnianego kościoła z 1717 roku, o którym niżej, możemy dość precyzyjnie odtworzyć, dzięki opisom archiwalnym i zachowanym w zbiorach Instytutu Sztuki Polskiej Akademii Nauk, szczegółowym rysunkom pomiarowym, jakie na zlecenie Towarzystwa Opieki nad Zabytkami Przeszłości wykonał ok. 1913 roku wybitny polski architekt, Ka-

${ }^{24} \mathrm{~W}$ tym miejscu należałoby pokrótce wyjaśnić, z czego taka lokalizacja omawianych budynków wynikała. Otóż układ ruralistyczny Zemborzyc, jaki powstał zapewne z chwili lokacji wsi na podstawie przywileju Kazimierza Wielkiego z 1364 roku (opublikowany w: Zbiór Dokumentów Małopolskich, Cz. 1, wyd. S. Kuraś, Warszawa 1962, s. 111), podobnie jak inne układy ruralistyczne wsi w okolicach Lublina, pochodzące z XIV i XV stulecia, złożony jest w obszarze zabudowy siedliskowej z rusztu dróg opartych na drodze równoległej do rzeki (zachowana częściowo, obecnie ul. Niezapominajki i Marzanny), położonej bezpośrednio nad nią, oraz równoległej do niej drogi między siedliskami a polami (obecnie ul. Krężnicka). Układ ten zadokumentowany jest na historycznych przekazach kartograficznych, w szczególności pochodzących sprzed oczynszowania i związanego z nim nowego podziału gruntów w latach 40. XIX stulecia (szerzej: H. Mącik, Zemborzyce w XIX wieku, w: Zemborzyce, red. H. Mącik, J. Chachaj, D. Szulc, Lublin 2016, s. 35-37), czyli zwłaszcza na zachowanej w wiedeńskim Kriegsarchiv tzw. Mapie Heldensfelda, ark. 195 z 1. 1801-1804 oraz w pochodzącym z 1823 roku „Brulionie wsi Zemborzyc i Wrotkowa” z 1823 roku, Archiwum Państwowe w Radomiu, zbiór Zarząd Dóbr Państwowych, sygn. 29. Droga nad rzeką, obecnie wyłącznie dojazdowa, była wówczas drogą ważniejszą, dlatego też starsze zemborzyckie kościoły stały przy niej, a zabudowania gospodarcze przy drodze tylnej, sąsiadującej z polami. Kiedy po kolejnych reformach przestrzennych wsi podejmowanych w XIX wieku obecna ul. Krężnicka stałą się główną drogą, zmienił się istotnie status położonych przy niej nieruchomości i dlatego też frontem do niej, na miejscu starych zabudowań gospodarczych, wystawiono w latach 1906-1907 nowy, murowany neogotycki kościół.

${ }^{25} \mathrm{~W}$ wizytacji z 1617 roku zakrystia nie jest wymieniona. Archiwum Kurii Metropolitalnej Krakowskiej (AKMKr), sygn. AV 6, Acta visitationis interioris archidiaconatus Lublinensis, cuius possesorem tangit ius visitandi in decanatibus Lucoviensi - Parczoviensi - Chodeliensi - Kasimiriensi et Solecensi in anno Domini 1617 diebus Junii et Julii, opera commisaria R.D. Jacobi Piaseczki, decani Kielcensis, canonici Posnaniensis confecta, k. 47v. W roku 1650 zakrystię opisano jako murowaną, sklepioną. AAL, sygn. Rep. 60, A, Vol. 97, Visitatio Ecclesiarum Archidiaconatu Lublinensi ex annis 1644 et 1650, k. 35v. 
zimierz Skórewicz ${ }^{26}$. Na rysunkach tych przedstawiono także elementy wystroju zakrystii: plecionkę ze szwów sklepienia oraz ozdobny kartusz herbowy z 1. poł. XVII wieku, złożony z ornamentów okuciowych i zwijanych. Niestety, inwentaryzator nie podał informacji, czy były to elementy kamienne, wykonane w zaprawie, czy też może dekoracja malarska. W zakrystii, przy północno-zachodnim narożniku był murowany kominek. Przedstawiony na kartuszu zinwentaryzowanym przez Skórewicza herb - odmiana herbu Odyniec, jest taki sam, jak herb znajdujący się na trzonie zachowanej w Zemborzycach kamiennej chrzcielnicy, z datą AD 1630 na czarze, co wskazywać może zarówno na datę budowy zakrystii, jak i jej potencjalnego fundatora, równocześnie fundatora chrzcielnicy. Herb na chrzcielnicy uzupełniony jest inicjałami AB CL PZ, takie same inicjały znajdowały się na kartuszu w zakrystii ${ }^{27}$. Inicjały te, a zatem także fundację murowanej zakrystii i kamiennej chrzcielnicy, można łączyć z ks. Andrzejem Bietkowiczem, kanonikiem lubelskim, kapelanem lubelskich brygidek, plebanem czerniejowskim ${ }^{28}$, a także zemborzyckim ${ }^{29}$.

Opisywany w osiemnastowiecznych wizytacjach drewniany kościół zemborzycki zbudowano, jak wskazuje na to lokalizacja starszej murowanej zakrystii, na miejscu poprzedniego, w $1717 \mathrm{roku}^{30}$. Remontowano go kilkukrotnie, m.in. po 1781 roku, gdy proboszczem zemborzyckim był ks. Krakowiecki oraz w 2. poł. XIX wieku. Znajdował się on na wschód od obecnego kościoła, przy dawnej głównej drodze przez wieś, biegnącej nad Bystrzycą.

Kościół był orientowany - skierowany prezbiterium na wschód, a frontem na zachód. Był to kościół trójnawowy (nawy boczne były bardzo wąskie) z prezbi-

${ }^{26}$ Zbiory Instytutu Sztuki Polskiej Akademii Nauk, sygn. 1200b, 1201b, 1202b i 1203b. Zachowane rysunki przedstawiają: sygn. $1200 \mathrm{~b}$ - plan sytuacyjny kościoła i sąsiednich zabudowań w skali 1:500, sygn. 1201b - rzut kościoła w skali 1:100, sygn. 1202b - przekrój przez korpus nawowy kościoła oraz przez zakrystię, bez podania skali liczbowej, ale z podziałką liniową, która dowodzi, że również skala tych rysunków to 1:100 oraz rysunek kraty zakrystii, sygn. $1203 \mathrm{~b}$ - rysunki profilu gzymsu zakrystii, plecionki na jej sklepieniu oraz kartusza herbowego nad oknem zakrystii.

${ }^{27}$ Jakkolwiek na rysunku K. Skórewicza widoczne są pewne różnice w stosunku do herbu na chrzcielnicy, to zarówno bardzo bliskie podobieństwo jak i pokrewieństwo stylistyczne obu kartuszy świadczy raczej o tym, że inwentaryzator nie mógł odczytać być może zatartego częściowo herbu i napisów, próbował zrekonstruować je nieprecyzyjnie, przez co np. belkę krzyża w godle herbowym połączył z inicjałem „L”. W Katalogu Zabytków Sztuki w Polsce, t. VIII, Województwo Lubelskie, z. 10, Powiat lubelski, red. R. Brykowski, E. Rowińska, Z. Winiarz-Tryzybowicz, Warszawa 1967, s. 44, podano błędnie odczytaną inskrypcję jako: AS CL PZ. R. Łoziński (Zemborzyce, s. 94) poprawnie odczytał herb Odyniec na chrzcielnicy, ale jednocześnie podał błędnie brzmienie inskrypcji za Katalogiem Zabytków Sztuki.

${ }^{28}$ J.A. Wadowski, Kościoły lubelskie, Kraków 1907, s. 457, przyp. 1. Ks. A. Bietkowicz był także współfundatorem murowanego kościoła w Czerniejowie, M. Kurzątkowski, Renesansowy kościót pw. św. Wawrzyńca w Czerniejowie, „Roczniki Humanistyczne”, 6 (1957) z. 4, s. 297.

${ }^{29}$ AKMKr, syg. A6, Acta visitationis interioris archidiaconatus Lublinensis, k. 47v.

${ }^{30}$ AAL, sygn. Rep. 60, A, Vol. 101: Acta visitationis decanatuum: Casimiriensis, Parzoviensis, Chodeliensis et Solecensis archidiaconatus Lublinensis et aliarum in archidiaconatu Zavichostensi ex annis 1736-1739, w opisie z roku 1739 zawartym w aktach tej księgi wizytacji zaznaczono, że kościół zemborzycki został „wystawiony przed 23 laty”. 
terium zamkniętym trójbocznie o szerokości równej głównej nawie. Całkowita długość kościoła wynosiła ok. 27 m, a szerokość korpusu naw ok. 10,5 m.

Przy budowie kościoła wykorzystano, opisaną wyżej, murowaną z cegły zakrystię, pochodzącą z XVII wieku, która przetrwała z wcześniejszej świątyni. Wnętrze kościoła było przekryte pozornym drewnianym spłaszczonym sklepieniem, wspartym na sześciu prostych drewnianych filarach wydzielających nawy. Prezbiterium kościoła było równej wysokości, co główna nawa, a jego dach posiadał kalenicę na tym samym poziomie co kalenica korpusu nawowego. Rysunki K. Skórewicza wskazują, że ściany kościoła wzniesiono w konstrukcji zrębowej, z zewnątrz, jak pokazuje to zachowana fotografia z początku XX wieku ${ }^{31}$, kościół był szalowany. Fasada poprzedzona była niewielką kruchtą na rzucie kwadratu, z której prowadziły do kościoła drzwi w ozdobnym snycerskim obramowaniu. Według inwentarza z 1849 roku, zachowanego w Archiwum Państwowym w Lublinie, fasada kościoła była malowana i ozdobiona rzeźbami, które jednak uległy zniszczeniu, jak zapisano: „,...) teraz jednak rzeźba opadła a malowania ledwo są ślady" ${ }^{32}$. Dwuspadowy dach, z ozdobną wieżyczką na sygnaturkę, kryty był pierwotnie gontem (tak go opisano w 1849 roku), który niedługo później zamieniono na blachę.

Według opisu w wizytacji kanonicznej parafii zemborzyckiej z 1748 roku kościół parafialny w Zemborzycach był wówczas starym drewnianym budynkiem, $\mathrm{z}$ podłogą i dachem wykonanym również $\mathrm{z}$ tego materiału. Posiadał on nowe okna, wykonane przed wspomnianą wizytacją. Kościół miał tylko jedno wejście, przez wielkie okute żelazem drzwi, zaopatrzone w żelazny zamek. Do drewnianego budynku kościoła przylegała stara, murowana i zadaszona zakrystia. Posiadała ona jedno zakratowane okno oraz okute drzwi zamykane żelaznym zamkiem. Stan zakrystii nie był najlepszy, skoro stwierdzono konieczność jej naprawy. W kościele, jak wynika z opisu, była również stara i zniszczona dzwonnica, w której wisiały dwa nowe dzwony ${ }^{33}$.

Wewnątrz świątyni znajdowało się pięć ołtarzy. W ołtarzu głównym był obraz Najświętszej Maryi Panny, od strony Ewangeliii ${ }^{34}$ św. Anny, a od strony Epistoły ${ }^{35}$ - Pana Jezusa. Boczne ołtarze kolatorskie, poświęcone były: św. Mikołajowi (po stronie Epistoły) oraz św. Jana Kantego (od strony Ewangelii). Wizerunki NMP i Jezusa musiały cieszyć się większą czcią, ponieważ przystrojono je w pozłacane srebrne korony z tzw. czeskimi kamykami ${ }^{36}$.

${ }^{31}$ Publikowana wcześniej m.in. przez Łozińskiego, Zemborzyce, s. 86.

${ }^{32}$ APL, sygn. 1684, Inwentarz 1849, brak paginacji.

${ }^{33}$ AAL, syg. A, nr 103, Status ecclesiarum parochialium decanatus, k. 193-193v.

${ }^{34}$ Lewa strona ołtarza. Przed Soborem Watykańskim II, kapłan z tej strony odczytywał Ewangelię. B. Nadolski, Orientacja (Conversi ad Dominum), w: Leksykon liturgii, red. B. Nadolski, Poznań 2006, s. 1132.

${ }^{35}$ Prawa strona ołtarza. Przed Soborem Watykańskim II, kapłan z tej strony czytał Listy Apostolskie. B. Nadolski, Orientacja (Conversi ad Dominum), w: Leksykon liturgii, red. B. Nadolski, Poznań 2006, s. 1132.

${ }^{36}$ Barwione szkiełka imitujące kamienie szlachetne. 
W kościele znajdowały się też m.in. dwa nowe konfesjonały, pokolorowane i częściowo złocone oraz sześć ławek, niedawno naprawionych. Ambona była drewniana, pomalowana na różne kolory, w części pozłacana i posrebrzana. Po stronie Ewangelii stała chrzcielnica $\mathrm{z}$ zamknięciem, malowana $\mathrm{w}$ różnych kolorach. W kościele był również stary, mały pozytyw w skrzyni, posiadający sześć głosów ${ }^{37}$.

Podczas wizytacji w roku 1781 po raz kolejny szczegółowo opisano kościół pw. św. bpa Marcina z Tours. Budynek nie wówczas w najlepszym ogólnym stanie. Stwierdzono m.in. że kościół ,trochę w ziemię wpadł”. Zniszczona była również podłoga, a ławki były połamane. Jednak rok przed wizytacją zostały wstawione nowe okna z ramami oraz przebudowano kruchtę kościoła. Dodatkowo stara dzwonnica kościelna została pokryta nowym dachem. W dzwonnicy wisiały dwa dzwony o średniej wielkości. Zaplanowano również wykonanie kolejnych kilku prac remontowych w świątyni, m.in. podmurówki kościoła, dlatego też zgromadzono materiał budowlany. Dodatkowo przygotowanych zostało kilkaset tarcic na wykonanie w kościele podłogi, ławek oraz obicia ścian świątyni. Zauważono, że naprawy potrzebowała również murowana zakrystia kościoła. Także drewniany parkan, którym był ogrodzony cmentarz, nie był w zadowalającym stanie, skoro wizytator nakazał go poprawić. Na cmentarzu natomiast wybudowana została nowa kostnica ${ }^{38}$.

W kościele zemborzyckim znajdowało się wówczas pięć ołtarzy uznanych za „staroświeckie”. W ołtarzu głównym był obraz Ukrzyżowanego Jezusa Chrystusa, a w czterech bocznych obrazy: Najświętszej Maryi Panny, św. Anny, św. Mikołaja i św. Jana Kantego. Obraz NMP ozdobiony był dwiema koronami srebrnymi, W części pozłacanymi. $Z$ opisu tego wynika, że być może obraz przedstawiał NMP z Dzieciątkiem. W kościele znajdowały się również obrazy, określone jako „stare”, które noszono podczas procesji. Były to wizerunki: św. Marcina, Ukrzyżowanego Jezusa Chrystusa, Matki Boskiej Częstochowskiej, Matki Boskiej Bolesnej i św. Józefa. Jedynie obraz przedstawiający uwiązanego przy słupie Jezusa Chrystusa był nowy. Część z tych wizerunków musiała cieszyć się większym kultem skoro przyozdabiano je wotami, sukienkami i koronami. Do obrazu Ukrzyżowanego Jezusa Chrystusa w wielkim ołtarzu, przyczepiono dziewięć drobnych „sztuczek” srebra. Natomiast wizerunek patrona kościoła św. Marcina, który był noszony w procesji, przyozdobiono w sukienkę, pastorał, infułę i rączkę. W kościele umieszczono również 16 srebrnych wotów, jednak nie podano przy jakim obrazie je zawieszono ${ }^{39}$.

W kościele znajdowały się dwa konfesjonały, które były pomalowane na niebiesko oraz ławki, które były „stare popsute”. Ambona była pomalowana na szafirowo. W kościele była również kamienna chrzcielnica z drewnianym przykryciem oraz naprawiony pozytyw o siedmiu głosach ${ }^{40}$.

\footnotetext{
${ }^{37}$ AAL, syg. A, nr 103, Status ecclesiarum parochialium decanatus; k. 193v-194.

${ }^{38}$ AAL, syg. A 105, Akta wizyty generalnej dekanatów, s. 140.

${ }^{39}$ Tamże, s. 141, 143.

${ }^{40}$ Tamże, s. 141
} 
W 1849 roku w zemborzyckim kościele były trzy ołtarze. Główny w prezbiterium, pod wezwaniem św. Marcina - patrona kościoła, był drewniany, ale miał murowaną mensę, a znajdowały się w nim obrazy Pana Jezusa Ukrzyżowanego, św. Marcina i św. Mikołaja. Dwa boczne drewniane ołtarze znajdowały się przy tęczy, na zakończeniu naw bocznych. W lewym znajdowały się obrazy św. Sebastiana, św. Antoniego i św. Jana Kantego, podczas gdy w prawym, Najświętszej Marii Panny i św. Anny ${ }^{41}$. Wzmianka z 1781 roku, o tym, że ówczesne ołtarze były zdaniem wizytującego staroświeckie, zmniejszenie liczby ołtarzy między 1781 a 1849 roku, a także sama klasycyzująca forma architektury zachowanych do dziś w Motyczu dwóch bocznych zemborzyckich ołtarzy, wskazuje, że mogły one zostać wykonane w końcu XVIII wieku, w związku z pracami remontowymi przy kościele, jakie podejmował ks. Krakowiecki. Jak wynika z zestawienia obrazów w bocznych ołtarzach w latach: 1781 i 1849, w dwóch nowszych ołtarzach zebrano przedstawienia, które wcześniej znajdowały się w czterech ołtarzach. Ambona była dostosowana stylistycznie do reszty wystroju - wszystkie jego elementy były malowane na niebiesko, ze złoceniami. W zachodniej części nawy znajdował się chór muzyczny z niewielkimi organami.

Kościół został ok. 1800 roku włączony w szerszą kompozycję przestrzenną: na jego osi zlokalizowano drogę prowadzącą do nowego cmentarza, założonego ok. $800 \mathrm{~m}$ na północny zachód od kościoła, na gruncie plebańskim ${ }^{42}$.

Po budowie istniejącego dziś murowanego kościoła, stara świątynia została w 1918 roku przeniesiona do Motycza, gdzie zestawiono kościół dla nowo powstałej parafii w 1922 roku ${ }^{43}$. Różnicą w stosunku do wyglądu kościoła w Zemborzycach przed przeniesieniem, było dodanie do prezbiterium dwóch symetrycznych zakrystii, niewielkim zmianom uległ także kształt okien w prezbiterium, a fasada kościoła zyskała neobarokowy ozdobny szczyt. Drobnym zmianom uległa także wieżyczka na sygnaturkę. Porównanie rysunków pomiarowych zemborzyckiego kościoła $\mathrm{z}$ fotografiami wnętrza kościoła po jego zestawieniu w Motyczu, wskazuje także, że po translokacji nieco inaczej potraktowano pozorne drewniane sklepienie kościoła, podnosząc jego strzałkę łuku. W ten sposób strop uzyskał formę naśladującą murowane sklepienie. Niestety, dawny zemborzycki kościół, jeden z ostatnich zabytków drewnianej architektury sakralnej

\footnotetext{
${ }^{41}$ APL, sygn. 1684, Inwentarz 1849, brak paginacji.

${ }^{42}$ Lokalizacja cmentarza, identyczna z dzisiejszą, została zadokumentowana na mapach z pocz. XIX stulecia: zachowanej w wiedeńskim Kriegsarchiv tzw. Mapie Heldensfelda, ark. 195 oraz w „Brulionie wsi Zemborzyc i Wrotkowa” z 1823 roku, Archiwum Państwowe w Radomiu, zbiór Zarząd Dóbr Państwowych, sygn. 29. Cmentarz jest wpisany do rejestru zabytków woj. lubelskiego, pod numerem A/947 decyzją z dnia 15 maja 1987. Poza kilkunastoma nagrobkami z 2. połowy XIX wieku (m.in. zemborzyckich proboszczów i małych dzieci z rodziny Ruedigerów) na szczególną uwagę zasługuje szpaler kilkudziesięciu lip posadzonych przy granicach pierwotnego obszaru cmentarza, których wiek można szacować na ok. 200 lat.

${ }^{43}$ H. Misztal, Wieś Motycz. Powstanie parafii i jej patronowie, w: Motycz. Nasza ojczyzna, red. H. Misztal, Motycz 2005, s. 13.
} 
okolic Lublina, spłonął podpalony 11 lipca 1994 roku $^{44}$. Z części uratowanego z pożaru drewna wybudowano niewielką kaplicę, stojącą do dziś przy nowym kościele. Szczęśliwie ocalały także XVIII-wieczne ołtarze z zemborzyckiego kościoła, przeniesione do Motycza w 1918 roku wraz z kościołem.

W Zemborzycach pozostały dziewiętnastowieczne obrazy z dawnych ołtarzy. Zachowały się w kościele także starsze zabytki: opisana wyżej chrzcielnica z 1. poł. XVII wieku i późnogotycki dzwon z pocz. XVI stulecia, jeden z najstarszych zabytków tego typu w regionie.

Starą zakrystię w Zemborzycach rozebrano, chociaż początkowo planowano jej przebudowę na kaplicęe ${ }^{45}$. Ostatecznie pozostały z niej tylko fragmenty murów, przysypane częściowo kopcem, widoczne do dziś na dawnym cmentarzu przykościelnym $^{46}$. Metrykę związaną z dawnym kościołem mają też niektóre drzewa zachowane między starym cmentarzem przykościelnym, a drogą biegnącą wzdłuż Bystrzycy.

Zachowany do dziś neogotycki kościół murowany powstał w latach 19061907, według projektu architekta z Radomia, Augusta Załuskiego, który swoją pracę wykonał za darmo. Budowę kościoła sfinansowali w całości parafianie, opodatkowując się dobrowolnie po 5 rubli od morgi ziemi. Do kościoła zakupiono także kompletny wystrój, utrzymany w neogotyckiej stylistyce, spójnej $\mathrm{z}$ architekturą kościoła ${ }^{47}$.

Jest to kościół trójnawowy, z prezbiterium nieznacznie węższym od nawy głównej, zamkniętym trójbocznie. Korpus nawowy na planie zbliżonym do kwadratu, jest utrzymany w systemie halowym. Od strony zachodniej kościół posiada dwuwieżową fasadę, stanowiącą dominantę architektoniczną okolicy.

Projekt nowego zemborzyckiego kościoła był wyraźnie inspirowany wcześniejszym o trzynaście lat, zwycięskim projektem konkursowym Stefana Szyllera na kościół w Dłutowie, publikowanym w „Przeglądzie Technicznym”48. O źródle inspiracji świadczy powtarzanie, niemal dosłowne, zarówno prawie całego rzutu dłutowskiego kościoła, jak i poszczególnych elementów bryły, czerpanych właśnie z opublikowanego projektu S. Szyllera, a nie z nieco w stosunku do niego skorygowanego, zrealizowanego w Dłutowie kościoła. Oba kościoły mają niemal

${ }^{44}$ J. Dmochowski, Historia parafii Motycz do 2001 r., w: Motycz. Nasza ojczyzna, red. H. Misztal, Motycz 2005, s. 49.

${ }^{45}$ Łoziński, Zemborzyce, s. 92.

${ }^{46}$ Ewentualne dalsze pozostałości starego kościoła, jak również układ przestrzenny pochówki na dawnym cmentarzu, mogłyby być ujawnione za pomocą badań archeologicznych. Dotychczas miejsce po dawnym zemborzyckim kościele nie było poddawane rozpoznaniu archeologicznemu.

${ }^{47}$ Szeroko okoliczności budowy tego kościoła oraz jego architekturę opisuje J. Żywicki, Architektura neogotycka na Lubelszczyźnie, Lublin 1998, s. 344-346, który jednak nie wskazał źródła inspiracji dla A. Załuskiego, jakim były projekty kościoła w Dłutowie na Mazowszu wykonane przez S. Szyllera.

${ }^{48}$ Wynik konkursu architektonicznego w Towarzystwie Zachęty Sztuk Pięknych w Królestwie Polskiem, „Przegląd Techniczny”, 20 (1894) nr 1, s. 24; Projekt kościoła parafialnego dla Dlutowa (w mławskiem) opracowany przez p. Stefana Szyllera budowniczego, „Przegląd Techniczny”, 20 (1894) nr 3, s. 67. O kościele w Dłutowie także: M. Omilanowska, Architekt Stefan Szyller 18571933, Warszawa 2008, s. 241-244. 
identyczny rzut poziomy: zbliżony do kwadratu trójprzęsłowy, trójnawowy korpus, podzielony na szerszą nawę, około dwukrotnie szerszą niż boczne, z dwuprzęsłowym prezbiterium zamkniętym trójbocznie, flankowanym przez dwie symetryczne zakrystie i z obszerną kruchtą od strony wejścia. Różnice w Zemborzycach dotyczą rezygnacji z obejścia wokół trójbocznego zamknięcia prezbiterium, rezygnacji z płytkich wnęk na osi poprzecznej korpusu nawowego oraz rezygnacji ze zróżnicowania skali i formy wież w fasadzie. Powtórzył Załuski za projektem Szyllera także inspirowane kamieniarką XV wieku, schodkowe obramienia portali i okien, także wokół okien naw bocznych, nie tylko fasady kościoła, jak to zrobił Szyller. Zasadniczą, oprócz innego zestawienia wież w fasadzie, różnicą w układzie bryły zemborzyckiego kościoła, jest jego układ halowy (nawy mają równe wysokości), zamiast bazylikowego (w którym nawa gówna jest wyższa od bocznych), zastosowanego w Dłutowie.

Przed remontami w latach 30. XX wieku elewacje zemborzyckiego kościoła wyglądały nieco inaczej niż dzisiaj. Publikowane w „Tygodniku Ilustrowanym” w 1908 roku fotografie kościoła wykonane bezpośrednio po ukończeniu budowy, ukazują elewacje, obecnie otynkowanych partii frontowej części kościoła, jako utrzymane w cegle, podobnie, jak zachowane do dziś elewacje boczne korpusu nawowego i prezbiterium oraz górne części wież $\dot{z}^{49}$. Ceglane elewacje wieńczył arkadkowy ostrołukowy fryz, fasada była zwieńczona wyższym niż obecnie szczytem, a szczyt między nawą a prezbiterium miał pięć wieżyczek, z których dziś istnieje tylko jedna, na kalenicy dachu nawy. Dookoła kościoła, w trakcie jego budowy wzniesiono także neogotyckie ogrodzenie z czterema kapliczkami.

Słowa kluczowe: Zemborzyce, parafia, kościół parafialny, pleban, Lubelszczyzna

\section{BIBLIOGRAFIA}

\section{Źródla rękopiśmienne}

Archiwum Archidiecezjalne Lubelskie (AAL)

sygn. Rep. 60, A nr 101: Acta visitationis decanatuum: Casimiriensis, Parzoviensis, Chodeliensis et Solecensis archidiaconatus Lublinensis et aliarum in archidiaconatu Zavichostensi ex annis 1736-1739.

sygn. Rep. A nr 103: Status ecclesiarum parochialium decanatus Parczoviensis et Chodeliensis ex anno 1748.

sygn. Rep A nr 105: Akta wizyty generalnej dekanatów: chodelskiego, urzędowskiego i kazimierskiego w diecezji krakowskiej z lat 1781-1782.

Archiwum Kurii Metropolitalnej Krakowskiej (AKMKr)

sygn. AV 6: Acta visitationis interioris archidiaconatus Lublinensis, cuius possesorem tangit ius visitandi in decanatibus Lucoviensi - Parczoviensi - Chodeliensi - Kasimiriensi et Solecensi in anno Domini 1617 diebus Junii et Julii, opera commisaria R.D. Jacobi Piaseczki, decani Kielcensis, canonici Posnaniensis confecta.

${ }^{49}$ „Tygodnik Ilustrowany”, (1908) nr 34, s. 686. 
sygn. Rep. 60, A, Vol. 97: Visitatio Ecclesiarum Archidiaconatu Lublinensi ex annis 1644 et 1650 .

Archiwum Państwowe w Lublinie

Komisja Województwa Lubelskiego i Rząd Gubernialny Lubelski, Wydział Administracyjny, sygn. 1684: Akta szczegółowe tyczące się Kościoła Zemborzyckiego funduszów i avuslów, vol. 1, Inwentarz Fundi Instructi Kościoła parafialnego Zemborzyckiego łącznie z filialnym Krężnickim...

Archiwum Państwowe w Radomiu

sygn. 29, „Brulion wsi Zemborzyc i Wrotkowa” 1823 r., zbiór Zarząd Dóbr Państwowych.

\section{Źródła ikonograficzne}

Instytut Sztuki Polskiej Akademii Nauk

sygn. 1200b, 1201b, 1202b i 1203b.

Kriegsarchiv w Wiedniu

tzw. Mapa Heldensfelda, ark. 195 z lat 1801-1804.

\section{Źródla drukowane}

Projekt kościoła parafialnego dla Dłutowa (w mławskiem) opracowany przez p. Stefana Szyllera budowniczego, „Przegląd Techniczny”, 20 (1894) nr 3, s. 67.

„Tygodnik Ilustrowany”, (1908) nr 34, s. 686.

Wynik konkursu architektonicznego w Towarzystwie Zachęty Sztuk Pięknych w Królestwie Polskiem, „Przegląd Techniczny”, 20 (1894) nr 1, s. 24.

Zbiór Dokumentów Małopolskich, cz. 1, wyd. S. Kuraś, Warszawa 1962.

\section{Opracowania}

Chachaj Jacek, Bliżej schizmatyków niż Krakowa... Archidiakonat lubelski w XV i XVI wieku, Lublin 2012.

Chachaj Jacek, Zemborzyce w XIV-XVIII w., w: Zemborzyce, red. H. Mącik, J. Chachaj, D. Szulc, Lublin 2016 (w serii: Lublin. 700-lecie. Historia dzielnic, red serii D. Szulc, H. Mącik), s. 18.

Dmochowski Józef, Historia parafii Motycz do 2001 r., w: Motycz. Nasza ojczyzna, red. H. Misztal, Motycz 2005, s. 49

Katalog Zabytków Sztuki w Polsce, t. VIII, Województwo Lubelskie, z. 10, Powiat lubelski, red. R. Brykowski, E. Rowińska, Z. Winiarz-Tryzybowicz, Warszawa 1967, s. 44.

Kurzątkowski Mieczysław, Renesansowy kościół pw. św. Wawrzyńca w Czerniejowie, „Roczniki Humanistyczne”, 6 (1957) z. 4, s. 297.

Łoziński Ryszard, Zemborzyce. Studia z dziejów wsi i dzielnicy miasta, Lublin 2005.

Mącik Hubert, Zemborzyce w XIX wieku, w: Zemborzyce, red. H. Mącik, J. Chachaj, D. Szulc, Lublin 2016, s. 35-37.

Misztal Henryk, Wieś Motycz. Powstanie parafii i jej patronowie, w: Motycz. Nasza ojczyzna, red. H. Misztal, Motycz 2005, s. 13.

Nadolski Bogusław, Orientacja (Conversi ad Dominum), red. B. Nadolski, Poznań 2006, s. 1128-1134.

Omilanowska Małgorzata, Architekt Stefan Szyller 1857-1933, Warszawa 2008.

Szczepaniak Jan, Spis prepozytów i plebanów diecezji krakowskiej (XVIII w.), Kraków 2008.

Wadowski Jan Ambroży, Kościoły lubelskie, Kraków 1907.

Żywicki Jerzy, Architektura neogotycka na Lubelszczyźnie, Lublin 1998. 


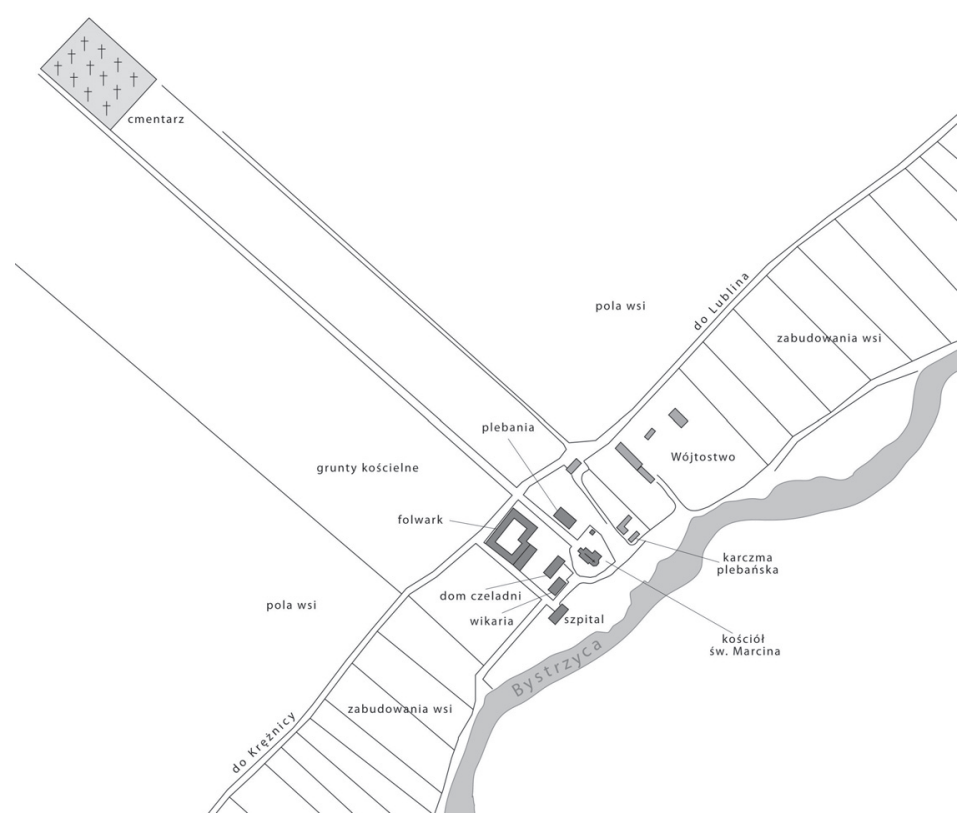

Fot. 1. Kościół w latach 1823 i 1849 - lokalizacja zabudowań kościelnych w Zemborzycach wg mapy z 1823 roku (Archiwum Państwowe w Radomiu, Zarząd Dóbr Państwowych, sygn. 29) i opisu z roku 1849 (Archiwum Państwowe w Lublinie, Komisja Województwa Lubelskiego i Rząd Gubernialny Lubelski, Wydział Administracyjny, sygn. 1684). Obecnie istniejący kościoł zlokalizowany jest na terenie dawnych zabudowań folwarku.

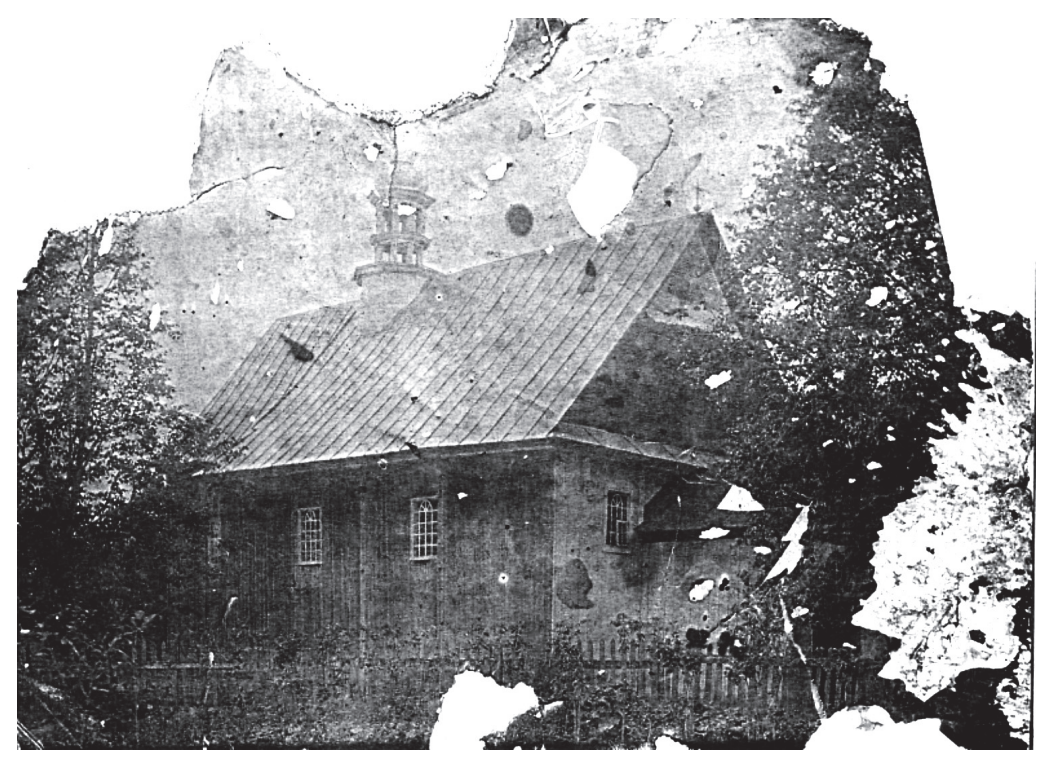

Fot. 2. Jedyna znana fotografia starego kościoła w Zemborzycach, wyk. ok. 1910 r. Zbiory autora. 


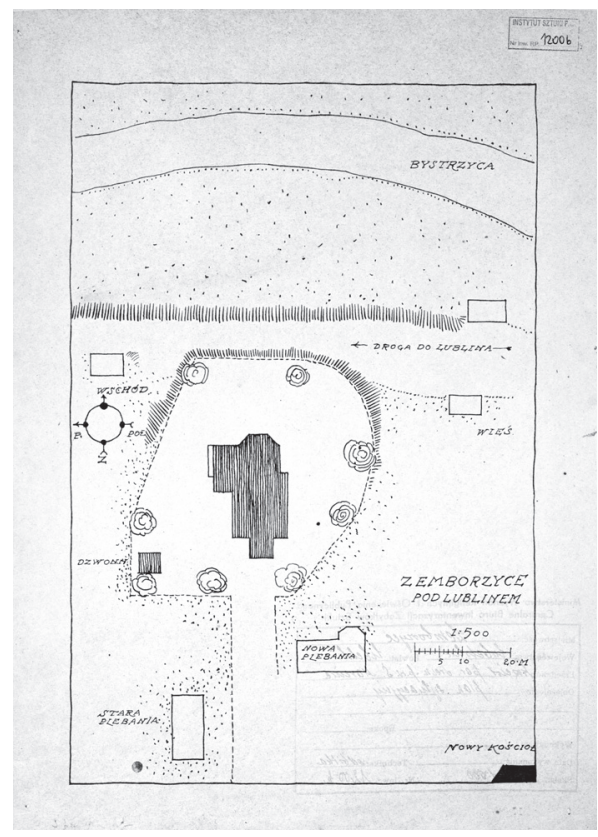

Fot. 3. Plan sytuacyjny kościoła w Zemborzycach i sąsiednich zabudowań, rys. K. Skórewicz, 1913 r. Zbiory Instytutu Sztuki Polskiej Akademii Nauk, sygn. 1200b.

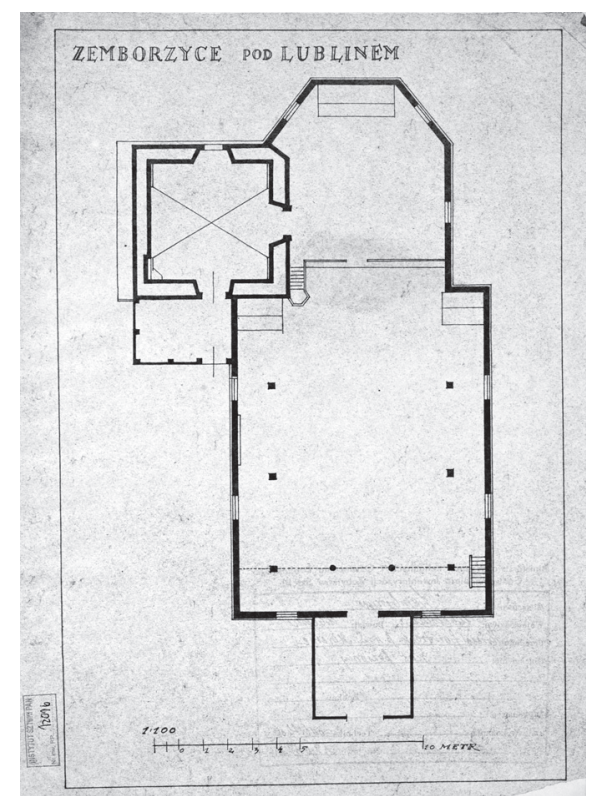

Fot. 4. Rzut kościoła w Zemborzycach, rys. K. Skórewicz, 1913 r. Zbiory Instytutu Sztuki Polskiej Akademii Nauk, sygn. 1201b. 


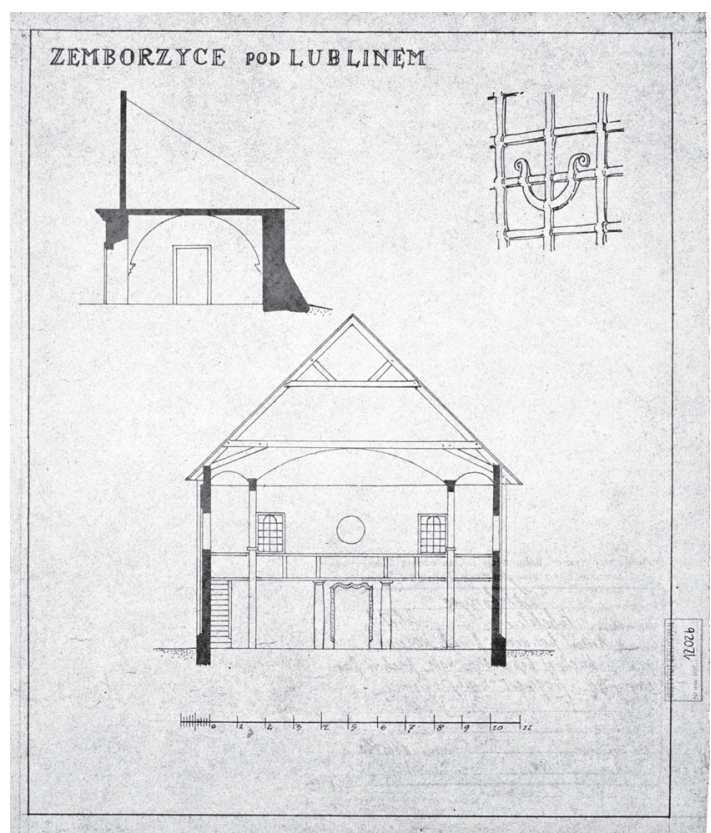

Fot. 5. Przekrój przez korpus nawowy oraz przez zakrystię kościoła w Zemborzycach, rys. K. Skórewicz, 1913 r. Zbiory Instytutu Sztuki Polskiej Akademii Nauk, sygn. 1202b.

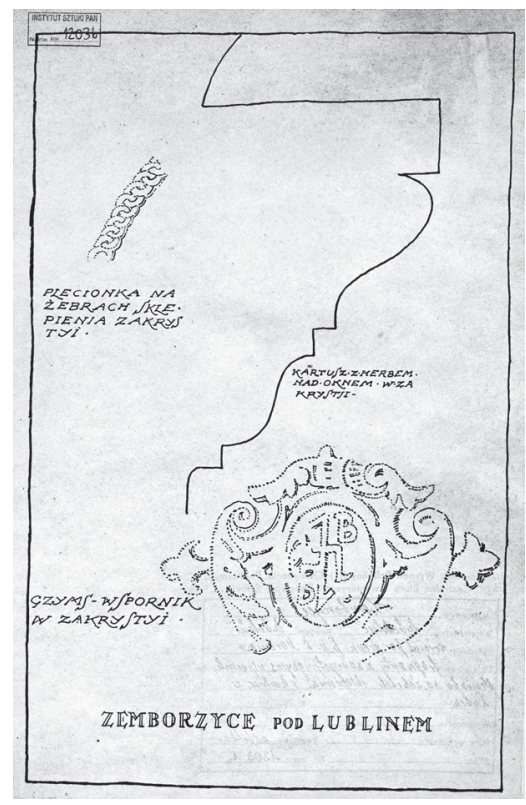

Fot. 6. Profil gzymsu, plecionka na sklepieniu oraz kartusz herbowy nad oknem zakrystii kościołą w Zemborzycach, rys. K. Skórewicz, 1913 r. Zbiory Instytutu Sztuki Polskiej Akademii Nauk, sygn. $1203 \mathrm{~b}$. 


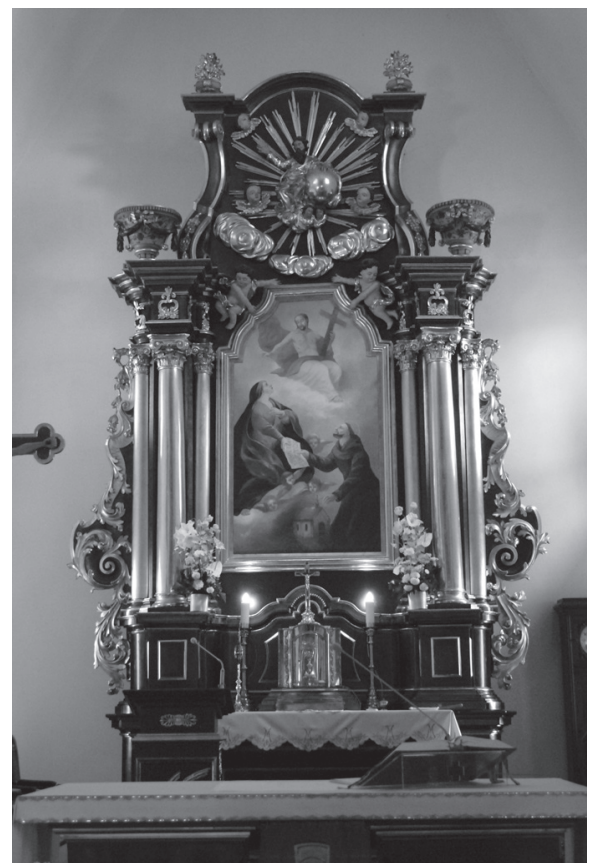

Fot. 7. Ołtarz wielki z kościoła w Zemborzycach, obecnie w kościele parafialnym w Motyczu, 2016 r. Fot. Hubert Mącik.

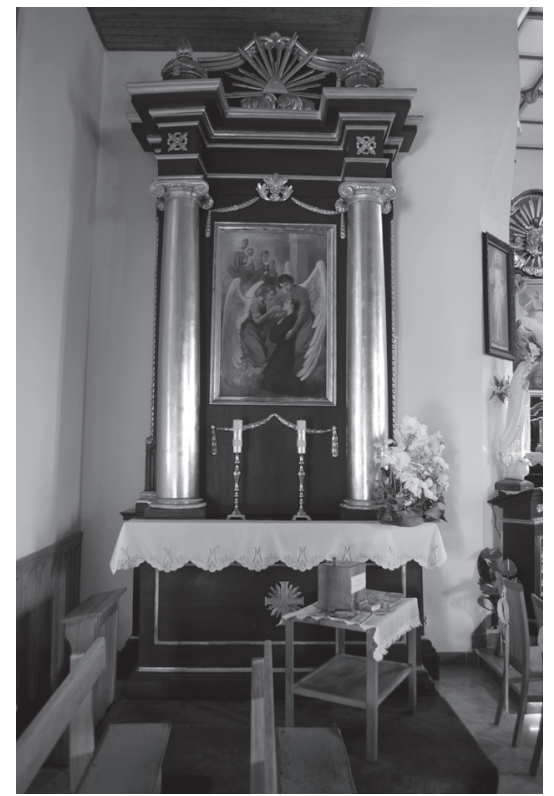

Fot. 8. Ołtarz boczny z kościoła w Zemborzycach, obecnie w kościele parafialnym w Motyczu, 2016 r. Fot. Hubert Mącik. 


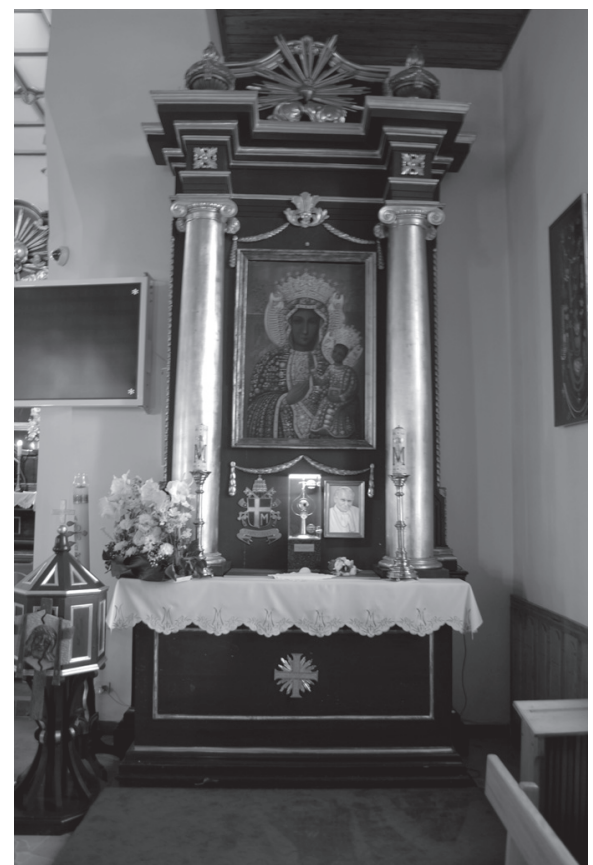

Fot. 9. Ołtarz boczny z kościoła w Zemborzycach, obecnie w kościele parafialnym w Motyczu, 2016 r. Fot. Hubert Mącik.

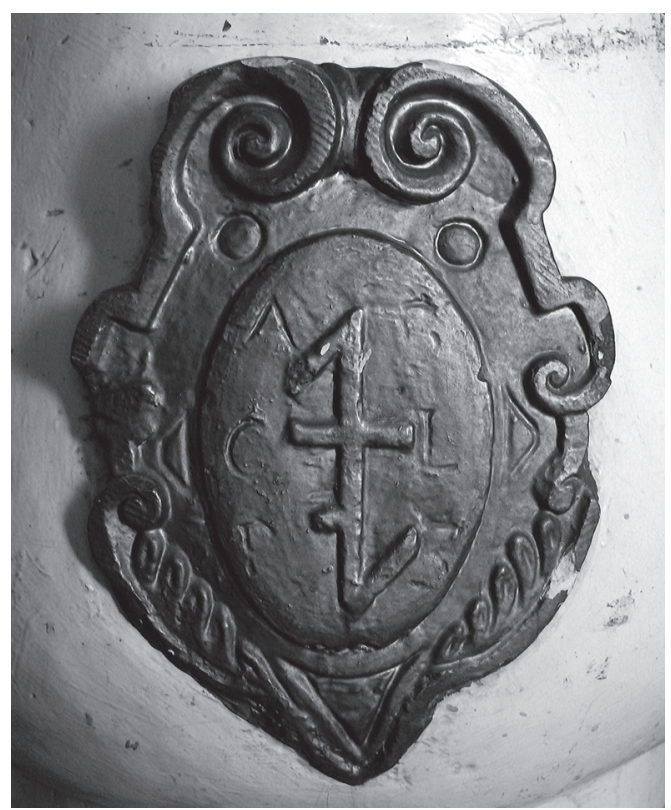

Fot. 10. Kartusz na chrzcielnicy w kościele w Zemborzycach, 2016 r. Fot. Hubert Mącik. 


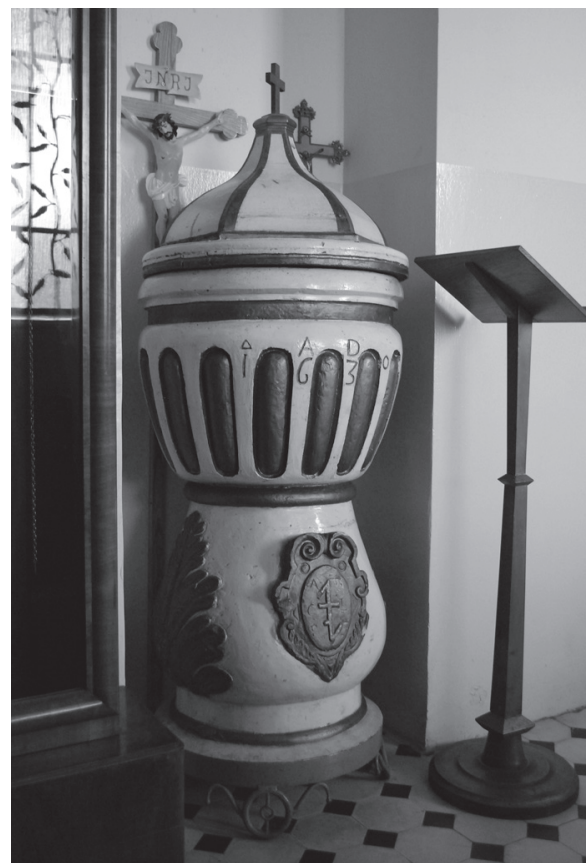

Fot. 11. Chrzcielnica w kościele w Zemborzycach, 2016 r. Fot. Hubert Mącik.

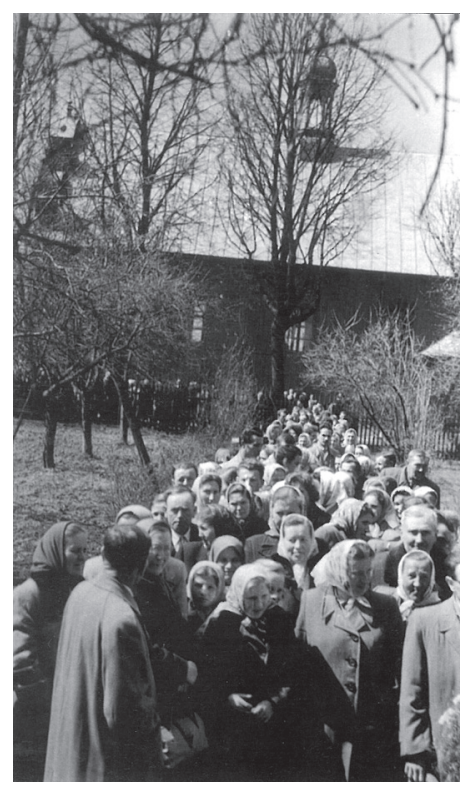

Fot. 12. Kościół z Zemborzyc w Motyczu, ok. 1970 r.

Fot. z: Motycz. Nasza ojczyzna, red. H. Misztal, Motycz 2005. 


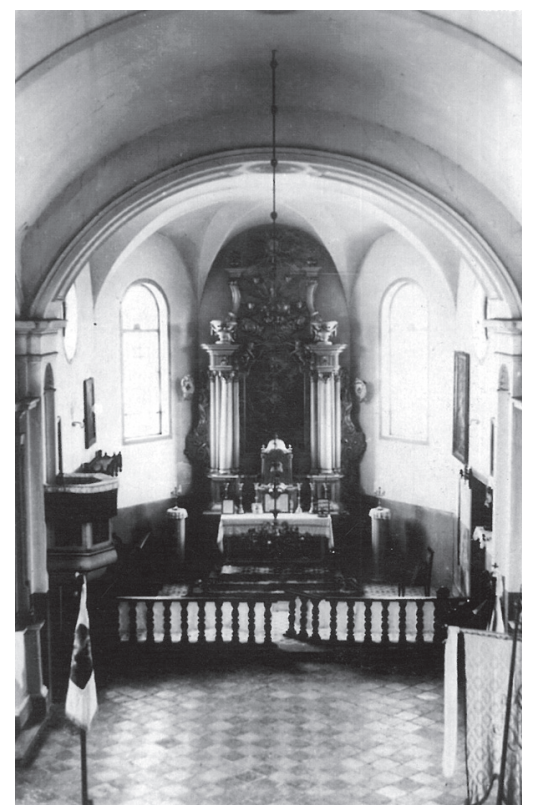

Fot. 13. Wnętrze kościoła przeniesionego z Zemborzyc do Motycza, ok. 1970 r. Fot. z: Nasza ojczyzna, red. H. Misztal, Motycz 2005.
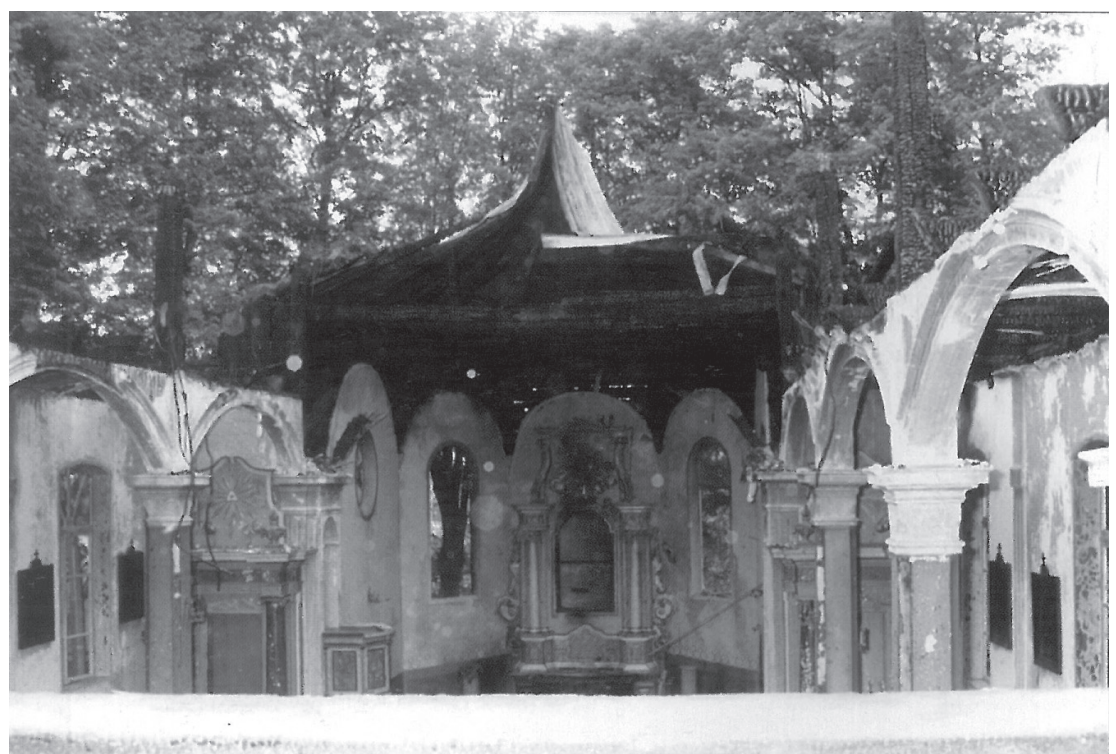

Fot. 14. Kościół z Zemborzyc po pożarze w Motyczu w 1994 r. Fot. z: Motycz. Nasza ojczyzna, red. H. Misztal, Motycz 2005. 


\title{
THE PARISH AND CHURCH IN ZEMBORZYCE IN THE 18TH AND 19TH CENTURIES
}

\begin{abstract}
Summary
The origins of the parish in Zemborzyce, which was probably created soon after the foundation of the village, dates back to the beginning of the 15 th century. In 1748, the parish of Zemborzyce consisted of six villages: Zemborzyce, Krężnica (a branch), Trzeszkowice, Osmolice, Prawiedniki and Żabia Wola. It was inhabited by approximately 2,000 faithful. In the parish there was a hospital, which was located in an old building. The parish endowment included arable land, a garden, the right to fish on the River Bystrzyca, a brewery and a taberna with propination laws. In 1779, a new presbytery was built. The outbuildings included: a farm house, a granary, a stable, a cowshed, a barn, a shed for oxen, small stables and pigsties. At the church square there was also a building for an organist. In 1784, a new hospital was built. In 1849, the buildings at the church, apart from the presbytery, included: a servants' house, a curate's house, a hospital, an inn and the following outbuildings: a stable, a coach house, a granary, a cowshed and a spacious barn. None of these buildings has survived until the present day.

The wooden church of Zemborzyce was built in 1717, in place of the previous one. It was renovated several times. It was located to the east of the present church, at the former main road through the village, running over the River Bystrzyca. After constructing the brick church, which exists today, the old church was moved to Motycze near Lublin in 1918. The neo-Gothic brick church, which survived to the present day, was built in 19061907. It was designed by the architect of Radom, Augusta Załuski.
\end{abstract}

Keywords: Zemborzyce, a parish, a parish church, a parish priest, the Lublin district 